\title{
Analysis of Microbial Parameters of Soil in Different Tillage Systems Under Sugar Beets (Beta vulgaris L.)
}

\author{
Alicja Niewiadomska ${ }^{1 *}$, Renata Gaj ${ }^{2}$, Jacek Przybył ${ }^{3}$, Anna Budka ${ }^{4}$, \\ Natalia Mioduszewska ${ }^{3}$, Agnieszka Wolna-Maruwka ${ }^{1}$ \\ University of Life Sciences, Poznań Poland \\ ${ }^{1}$ Department of General and Environmental Microbiology \\ ${ }^{2}$ Department of Agricultural Chemistry and Environmental Biogeochemistry \\ ${ }^{3}$ Institute of Agricultural Engineering \\ ${ }^{4}$ Department of Mathematical and Statistical Methods
}

Received: 16 February 2016

Accepted: 12 April 2016

\begin{abstract}
Evaluating the impact of cultivation systems for improving the management of agricultural soil is difficult. Traditional ploughing cultivation can contribute to soil erosion. An alternative to conventional tillage is conservation tillage. The aim of our study was to determine the influence of different cultivation systems on the biochemical and biological activity of soil under sugar beets. The conventional tillage treatment with soil ploughing to a depth of $35 \mathrm{~cm}$ was the control treatment (CT). For comparison, we analysed the following conservation tillage systems consisting of shallow or deep-soil ripping:

1. Tillage to a depth of $35 \mathrm{~cm}$ and sowing into stubble mulch (MS35).

2. Tillage to a depth of $15 \mathrm{~cm}$ and sowing into stubble mulch (MS15).

3. Tillage to a depth of $15 \mathrm{~cm}$ and sowing into white mustard mulch (MG).

4. Strip-till on stubble mulch to a depth of $25 \mathrm{~cm}$ and instantaneous beet seed sowing (STS).

5. Strip-till to a depth of $25 \mathrm{~cm}$ on white mustard mulch and instantaneous beet seed sowing (STG).

The soil samples that were used for biochemical and microbiological analyses were collected during four terms in each year, which coincided with the four consecutive stages of the development of sugar beets.

During both years of research we obtained results concerning the influence of different soil cultivation methods on the number of selected groups of soil microorganisms and the enzymatic activity under sugar beets. In 2012-13 the highest bioactivity was noted in the period of the greatest demand of sugar beets for nutrients, at the phase when the rows of plants were closing in. At that time the content of actinobacteria in the soil collected from the sites where STS had been applied was $42 \%$ greater than in the soil from the
\end{abstract}

*e-mail: alicja.niewiadomska@onet.eu 
ploughing cultivation system. Apart from that, in this same term, whenever conservation tillage was applied the activity of dehydrogenases and phosphatases always increased.

Keywords: dehydrogenase activity, phosphatase activity, conservation tillage, number of microoganisms

\section{Introduction}

In Europe sugar beets are chiefly cultivated to obtain the raw material that is processed into sugar. However, in recent years the potential use of this crop has grown considerably. At the end of the $20^{\text {th }}$ century the goal of cultivation has been, i.e., protection of the soil and water environments and economic rationalization of costs, leading to the reduction of outlay on production.

Agriculture faced these problems by introducing sustainable farming systems on a larger scale. In these systems plough farming is often abandoned in favour of other solutions. Changes in farming trends involve reducing the number of field passes by aggregation of farming machinery, minimizing the number of farming procedures, limiting ploughing, and introducing technologies that enable precise mixing of straw and crop residues with soil and their quick mineralization. The conservation tillage technology that is applied to sow wide rows of spring crops (e.g., sugar beets) follows the concept of sustainable farming. According to the published data [1-3], the yield of sugar beets cultivated in this system is relatively high and is comparable to the yield from conventional farming. Apart from that, according to Weber [4] and Kladivko [5], this cultivation system has a favourable influence on protecting the soil environment as it increases the content of organic matter and microelements and it stimulates biological diversity. When the effect of different agro-technological procedures and chemical factors on the state of soil is diagnosed, enzymatic and microbial activities are considered to be good indicators of the soil environment quality due to their high sensitivity and quick reaction. The monitoring of the pedosphere with the methods based on enzymatic tests enables a complex assessment of the changes that take place in the soil environment as a result of the cultivation system [6]. Dehydrogenases and phosphatases (acid and alkaline) are the most commonly investigated soil enzymes because they exhibit noticeable reactions to stress factors [7]. The activity of dehydrogenases is related to the activity of many enzymatic systems that can commonly be found in soil microorganisms (both aerobic and anaerobic) [8-10]. The usefulness of measuring these bio-indicators as an ecological test has been confirmed by numerous studies on changes in bioactivity depending on different cultivation and fertilization systems [11-13]. On the other hand, the activity of phosphatases - especially acid phosphatase $(\mathrm{Pac})$ - is related to changes in the physiochemical properties of soil, i.e., soil $\mathrm{pH}$, hydrolytic activity, and soil porosity.

The influence of different sugar beet conservation tillage systems, where stubble intercrops (mulch) are applied, has been well investigated in terms of the yield and technological value of the roots. However, there are no publications with the results of research on the microbial activity of soil, in the aspect of protecting the soil environment with the different conservation tillage system used.

The aim of this study was to determine the influence of different cultivation systems on the number of microorganisms (total numbers of bacteria, fungi, and actinobacteria) and the enzymatic activity (dehydrogenases and phosphatases) under sugar beets.

\section{Materials and Methods}

The study was carried out in 2012-13 at the Żołędnica Animal Breeding Establishment $\left(51.65^{\circ} \mathrm{N} 16.90^{\circ} \mathrm{E}\right)$ located in the vicinity of Rawicz (central Poland). The experiment was arranged following the randomized complete block design.

Six differentiated technologies with reference to tillage methods and mulch materials constituted the experimental factor. The conventional tillage treatment with soil ploughing to a depth of $35 \mathrm{~cm}$ was the control treatment (CT). For comparison we analyzed the following conservation tillage systems consisting of shallow or deep-soil ripping:

1. Tillage to a depth of $35 \mathrm{~cm}$ and sowing into stubble mulch (MS35).

2. Tillage to a depth of $15 \mathrm{~cm}$ and sowing into stubble mulch (MS15).

3. Tillage to a depth of $15 \mathrm{~cm}$ and sowing into white mustard mulch (MG).

4. Strip-till on stubble mulch to a depth of $25 \mathrm{~cm}$ and instantaneous beet seed sowing (STS).

5. Strip-till to a depth of $25 \mathrm{~cm}$ on white mustard mulch and instantaneous beet seed sowing (STG).

Table 1. Basic physical and chemical properties of studied soils.

\begin{tabular}{|c|c|c|c|c|c|c|c|c|}
\hline Years & $\begin{array}{c}\mathrm{P} \\
\text { available } \\
\left(\mathrm{mg} \cdot \mathrm{kg}^{-1}\right)\end{array}$ & $\begin{array}{c}\mathrm{K} \\
\text { available } \\
\left(\mathrm{mg} \cdot \mathrm{kg}^{-1}\right)\end{array}$ & $\begin{array}{c}\mathrm{Mg} \\
\text { available } \\
\left(\mathrm{mg} \cdot \mathrm{kg}^{-1}\right)\end{array}$ & Sand (\%) & Silt (\%) & Clay (\%) & $\begin{array}{c}\text { Organic } \\
\mathrm{C}\left(\mathrm{g}_{\mathrm{kg}}^{-1}\right)\end{array}$ & $\mathrm{pH} \mathrm{1M} \mathrm{KCl}$ \\
\hline 2012 & 130 & 106 & 68 & 78 & 20 & 2 & 9.3 & 6.2 \\
\hline 2013 & 88 & 165 & 72 & 81 & 17 & 2 & 8.8 & 7.0 \\
\hline
\end{tabular}


Table 2. Mineral fertilization levels $\left(\mathrm{kg} \cdot \mathrm{ha}^{-1}\right)$ in 2012 and 2013.

\begin{tabular}{|c|c|c|c|c|}
\hline \multirow{2}{*}{ Years } & \multicolumn{4}{|c|}{ Nutrients } \\
\cline { 2 - 5 } & $\mathrm{N}$ & $\mathrm{P}$ & $\mathrm{K}$ & $\mathrm{Mg}$ \\
\hline 2012 & 90 & 11 & 129 & 4 \\
\hline 2013 & 125 & 9 & 33 & 4 \\
\hline
\end{tabular}

In both years of observations, winter wheat was used as the previous crop for sugar beets. Wheat straw was removed from the field after harvesting. Soil experimental plots, according the FAO/WRB classification (as a typical lessive soil formed from light loamy sands), were deposited in the shallow layer on light loam (haplic luvisols), with high contents of available phosphorus, and medium contents of available potassium and magnesium. Soil reaction was slightly acidic in the first year of observations and neutral in the second year. Soil physico-chemical data is presented in Table 1. All cultivation procedures were conducted according to the rules of correct sugar beet agritechnology and appropriate fertilization. Phosphorous was applied as a compound fertilizer, type PK (10:30), and potassium was additionally supplied as 40\% potassium salt (type Korn-Kali). Phosphorus and potassium fertilizers were applied in the autumn. Magnesium was applied twice as foliar treatment using Epsom salt $\left(\mathrm{MgSO}_{4} \cdot 7 \mathrm{H}_{2} \mathrm{O}\right)$ (Table 2).

The climate of the region where the experiment was located is affected by clashing air masses from the Atlantic Ocean and from Eastern Europe and Asia. It is modified periodically by Arctic or Mediterranean influences. The average temperatures noted in the region in long-term periods range from $-2.8^{\circ} \mathrm{C}$ to $-1.5^{\circ} \mathrm{C}$ in January, and from $17.6^{\circ} \mathrm{C}$ to $18^{\circ} \mathrm{C}$ in July. The Greater Poland region is located in the zone of the lowest rainfall in Poland, where the long-term average annual rainfall is $500-600 \mathrm{~mm}$. During the experiment the rainfall was more favourable in 2013 than in 2012 and the monthly rainfall averages were $46.81 \mathrm{~mm}$ and $45.96 \mathrm{~mm}$, respectively (Table 3 ).

The soil samples used for biochemical and microbiological analyses were collected in four terms that coincided with the four consecutive stages of development of sugar beets: term 1 (before sowing), term 2 (the stage of six true leaves: $\mathrm{BBBCH} 16 / 17)$, term 3 (the stage of plants closing rows: $\mathrm{BBCH} 39 / 40$ ), and term 4 (technological maturity: $\mathrm{BBCH} 49$ ).

\section{Enumeration of Selected Microorganisms}

The plate method was applied to determine the populations of microorganisms in soil samples collected from under the plants at a depth of $0-20 \mathrm{~cm}$. Soil microorganisms were counted on adequate agar substrate (in five replications) and expressed in colony-forming units (cfu) $\mathrm{g}^{-1} \mathrm{DW}$ of soil. The total number bacteria was determined on Merck-Standar agar after 72 hours of incubation at $25^{\circ} \mathrm{C}$, fungi were determined on a Martin [14] medium after five days of incubation at $24^{\circ} \mathrm{C}$, and actinobacteria were assessed on a Pochon medium after 5-7 days of incubation at $25^{\circ} \mathrm{C}$ [15].

\section{Soil Enzymatic Activity}

The analysis of enzymatic activity of soil in different cultivation variants was based on the colorimetric method applied to measure dehydrogenases activity (DHA), where $1 \%$ triphenyl tetrazolium chloride (TTC) was used as a substrate. The measurement took place after 24 hours of incubation at $30^{\circ} \mathrm{C}$ and a wavelength of $485 \mathrm{~nm}$, and it was expressed in $\mu \mathrm{mol}$ TPF $24 \mathrm{~h}^{-1} \mathrm{~g}^{-1} \mathrm{DM}$ of soil [16].

The biochemical analyses of soil involved the determination of activities of acid (EC3.1.3.1) and alkaline (EC 3.1.3.2) phosphomonoesterases (PAC and PAL) using the method of Tabatabai and Bremner [17]. The activities were determined using as substrate disodium p-nitrophenyl phosphate tetrahydrate, after $1 \mathrm{~h}$ incubation at $37^{\circ} \mathrm{C}$ at a wavelength of $400 \mathrm{~nm}$. Results were converted into $\mu \mathrm{mol}$ p-nitrophenol PNP) $\mathrm{h}^{-1} \cdot \mathrm{g}^{-1} \mathrm{DM}$ of soil.

The dynamics of change in the microbial composition of soil and enzymatic activity were analysed statistically. The results were subjected to two factorial analysis of variance by means of the Statistica 9.1 program. A two-way ANOVA was carried out to determine the effects of the cultivation methods and interaction of the cultivation methods and the time of analysis. For F-test showing significant differences, Tukey's test (HSD) at the probability level $\alpha=0.05$ was additionally performed to

Table 3. Meteorological parameters in 2012 and 2013.

\begin{tabular}{|c|c|c|c|c|c|c|c|c|c|c|c|c|c|c|}
\hline \multicolumn{2}{|c|}{ Month } & I & II & III & IV & $\mathrm{V}$ & VI & VII & VIII & IX & $X$ & XI & XII & Mean \\
\hline \multirow{3}{*}{$\begin{array}{c}\text { Temperature } \\
\left({ }^{\circ} \mathrm{C}\right)\end{array}$} & $\begin{array}{l}\text { Mean of } \\
\text { multi-year }\end{array}$ & 1.03 & -0.3 & 3.53 & 8.90 & 14.24 & 17.09 & 19.37 & 18.76 & 13.97 & 8.96 & 3.59 & 0.4 & 8.96 \\
\hline & 2012 & 0.6 & -4.4 & 5.8 & 11.36 & 15.7 & 16.84 & 19.84 & 19.42 & 14.48 & 8.3 & 5.35 & -1.5 & 9.32 \\
\hline & 2013 & 2.26 & -0.3 & -2.1 & 8.3 & 14.6 & 17.5 & 20.21 & 19.19 & 12.59 & 10.4 & 4.8 & 2.9 & 8.81 \\
\hline \multirow{3}{*}{$\begin{array}{l}\text { Precipitation } \\
\quad(\mathrm{mm})\end{array}$} & $\begin{array}{l}\text { Mean of } \\
\text { multi-year }\end{array}$ & 33 & 29 & 35 & 36 & 46 & 59 & 83 & 63 & 42 & 39 & 37 & 44 & 45.5 \\
\hline & 2012 & 55.7 & 26.2 & 32.8 & 21.8 & 73.6 & 90.4 & 48.4 & 54.1 & 83.4 & 6 & 38.7 & 20.5 & 45.96 \\
\hline & 2013 & 61.8 & 41.1 & 11.2 & 19.8 & 38.5 & 91.3 & 93.5 & 90.8 & 29.1 & 30 & 27.3 & 27.3 & 46.81 \\
\hline
\end{tabular}


Table 4. $F$ test statistics and significance levels of two-way analysis of variance for the number of selected groups of microorganisms associated; with tillage systems and terms research fixed factors $(* * * p=0.001 ; * * p=0.01 ; * p=0.05$; ns - not statistically significant).

\begin{tabular}{|c|c|c|c|}
\hline Parameter & $\begin{array}{c}\text { Tillage } \\
\text { systems }\end{array}$ & Term & Interaction \\
\hline \multicolumn{3}{|c|}{$\mathbf{2 0 1 2}$} \\
\hline $\begin{array}{c}\text { Total number } \\
\text { bacteria }\end{array}$ & $47.181^{* * *}$ & $116.230^{* * *}$ & $42.002^{* * *}$ \\
\hline Actinobacteria & $20.164^{* * *}$ & $148.395^{* * *}$ & $8.977^{* * *}$ \\
\hline Fungi & $44.183^{* * *}$ & $504.282^{* * *}$ & $28.628^{* * *}$ \\
\hline \multicolumn{4}{|c|}{$\mathbf{2 0 1 3}$} \\
\hline $\begin{array}{c}\text { Total number } \\
\text { bacteria }\end{array}$ & $6.444^{* * *}$ & $111.895^{* * *}$ & $4.797^{* * *}$ \\
\hline \begin{tabular}{c} 
Actinobacteria \\
\hline Fungi
\end{tabular} & $4.928^{* * *}$ & $263.263^{* * *}$ & $9.150^{* * *}$ \\
\hline $6.122^{* * *}$ & $57.095^{* * *}$ & $16.327^{* * *}$ \\
\hline
\end{tabular}

compare mean values. Data analysis was performed using the statistical package STATISTICA 9. We used principal component analysis (PCA) to analyse the biological activity data resulting from the effect of the cultivation method at individual stages of sugar beet development.

\section{Results and Discussion}

There are various and numerous interactions between the physical, chemical, and biological properties of soil, but microorganisms are the most significant elements in the functioning of the soil ecosystem [18]. They are attributed to a key role in controlling the reactions that are necessary to maintain soil fertility and structure. The interaction between microorganisms and plants leads to a specific balance in the biocenosis system, which may be disturbed by each new inflow of nutrients or chemicals or by a sudden change in the physiochemical properties of soil.

During two consecutive years of research we obtained results concerning the influence of different soil cultivation methods on the populations of selected groups of soil microorganisms under sugar beets. The two-factor analysis of variance proved that during both years of research the factors under investigation had a highly significant influence $(\alpha=0.001)$ on the dynamics of changes in the populations of selected groups of soil microorganisms (Table 4). In both 2012 and 2013 all of the soil cultivation methods had a highly significant influence on the populations of selected groups of soil microorganisms (bacteria, actinobacteria, and fungi) (Table 5). The cultivation method affects the physical and chemical properties of soil, and thus provide the soil conditions for the development of crops and for

Table 5. The number of a selected group of microorganisms under the cultivation of sugar beets in 2012 .

\begin{tabular}{|c|c|c|c|c|c|c|}
\hline \multirow{2}{*}{ Term of analysis } & \multicolumn{6}{|c|}{ Experimental combination } \\
\hline & $\mathrm{CT}$ & MS35 & MS15 & MG & STS & STG \\
\hline \multicolumn{7}{|c|}{ Total number bacteria $\left(\mathrm{cfu} \cdot \mathrm{g}^{-1} \mathrm{dm}\right.$ soil $\left.\cdot 10^{5}\right)$} \\
\hline Before sowing & $27.46 \mathrm{c}-\mathrm{f} \pm 3.6$ & $31.61 \mathrm{~cd} \pm 2.3$ & $41.59 \mathrm{ab} \pm 4.5$ & $37.49 \mathrm{c} \pm 0.6$ & $40.83 \mathrm{ab} \pm 0.6$ & $89.65 \mathrm{a} \pm 1.9$ \\
\hline BBCH16/17 & $12.61 \mathrm{fg} \pm 4.1$ & $21.75 \mathrm{~d}-\mathrm{g} \pm 3.4$ & $15.37 \mathrm{e}-\mathrm{g} \pm 2.8$ & $27.79 \mathrm{c}-\mathrm{f} \pm 4.2$ & $76.76 \mathrm{a} \pm 1.6$ & $32.04 \mathrm{~cd} \pm 6.9$ \\
\hline $\mathrm{BBCH} 39 / 40$ & $28.97 \mathrm{c}-\mathrm{e} \pm 2.2$ & $30.07 \mathrm{c}-\mathrm{e} \pm 5.6$ & $12.75 f g \pm 4.6$ & $54.04 \mathrm{~b} \pm 3.2$ & $74.26 \mathrm{~cd} \pm 4.2$ & $34.61 \mathrm{e}-\mathrm{g} \pm 2.7$ \\
\hline Technological maturity & $11.35 \mathrm{~g} \pm 3.5$ & $12.78 \mathrm{fg} \pm 3.1$ & $6.52 \mathrm{~g} \pm 2.1$ & $35.19 \mathrm{~cd} \pm 5.9$ & $10.64 \mathrm{~g} \pm 1.2$ & $8.40 \mathrm{~g} \pm 1.6$ \\
\hline \multicolumn{7}{|c|}{ Actinobacteria $\left(\mathrm{cfu} \cdot \mathrm{g}^{-1} \mathrm{dm}\right.$ soil $\left.\cdot 10^{5}\right)$} \\
\hline Before sowing & $31.98 \mathrm{e}-\mathrm{j} \pm 2.3$ & $53.92 \mathrm{~d}-\mathrm{g} \pm 5.3$ & $65.37 \mathrm{c}-\mathrm{f} \pm 3.2$ & $22.64 \mathrm{f}-\mathrm{j} \pm 3.4$ & $49.73 \mathrm{~d}-\mathrm{h} \pm 3.5$ & $71.87 \mathrm{~cd} \pm 4.2$ \\
\hline $\mathrm{BBCH} 16 / 17$ & $49.66 \mathrm{~d}-\mathrm{h} \pm 3.2$ & $80.62 b-d \pm 4.2$ & $29.98 \mathrm{e}-\mathrm{j} \pm 3.2$ & $78.11 \mathrm{~b}-\mathrm{d} \pm 5.4$ & $115.14 \mathrm{ab} \pm 2.2$ & $68.23 \mathrm{c}-\mathrm{e} \pm 3.1$ \\
\hline ВBCH39/40 & $93.25 \mathrm{a}-\mathrm{c} \pm 6.3$ & $75.89 \mathrm{~cd} \pm 5.5$ & $66.93 \mathrm{c}-\mathrm{f} \pm 2.4$ & $49.48 \mathrm{~d}-\mathrm{h} \pm 3.2$ & $123.77 \mathrm{a} \pm 5.2$ & $124.87 \mathrm{a} \pm 5.3$ \\
\hline Technological maturity & $13.54 \mathrm{~h}-\mathrm{j} \pm 5.4$ & $6.21 \mathrm{j} \pm 1.6$ & $4.35 \mathrm{j} \pm 1.1$ & $4.72 \mathrm{j} \pm 2.2$ & $12.47 \mathrm{ij} \pm 0.6$ & $18.89 \mathrm{~g}-\mathrm{j} \pm 2.6$ \\
\hline \multicolumn{7}{|c|}{ Fungi $\left(\mathrm{cfu} \cdot \mathrm{g}^{-1} \mathrm{dm}\right.$ soil $\left.\cdot 10^{4}\right)$} \\
\hline Before sowing & $27.46 \mathrm{~cd} \pm 3.6$ & $31.61 b c \pm 2.3$ & $41.59 \mathrm{~b} \pm 4.4$ & $37.49 \mathrm{bc} \pm 0.6$ & $40.83 b \pm 0.6$ & $89.64 a \pm 5.9$ \\
\hline BBCH16/17 & $3.44 \mathrm{fg} \pm 2.2$ & $18.37 \mathrm{de} \pm 3.2$ & $3.75 \mathrm{fg} \pm 1.2$ & $4.13 \mathrm{fg} \pm 0.6$ & $4.18 \mathrm{fg} \pm 1.7$ & $10.18 \mathrm{e}-\mathrm{g} \pm 1.1$ \\
\hline $\mathrm{BBCH} 39 / 40$ & $2.47 \mathrm{fg} \pm 1.2$ & $2.44 \mathrm{fg} \pm 1.1$ & $8.85 \mathrm{e}-\mathrm{g} \pm 4.02$ & $11.92 \mathrm{e}-\mathrm{g} \pm 3.1$ & $12.59 \mathrm{e}-\mathrm{g} \pm 3.7$ & $13.56 \mathrm{ef} \pm 5.5$ \\
\hline Technological maturity & $2.56 \mathrm{fg} \pm 1.6$ & $1.46 \mathrm{~g} \pm 0.6$ & $2.84 \mathrm{fg} \pm 0.5$ & $3.73 \mathrm{fg} \pm 1.7$ & $4.90 \mathrm{fg} \pm 0.6$ & $4.71 \mathrm{fg} \pm 0.4$ \\
\hline
\end{tabular}

Mean values \pm standard errors; different letters denote statistical differences at level $\alpha=0.05 ; \mathrm{n}=5$.

Abbreviations for Tables 5-6: CT - control treatment, MS35 - tillage to a depth of $35 \mathrm{~cm}$ and sowing into stubble mulch, MS15 tillage to a depth of $15 \mathrm{~cm}$ and sowing into stubble mulch, MG tillage to a depth of $15 \mathrm{~cm}$ and sowing into white mustard mulch, STS strip-till on stubble mulch to a depth of $25 \mathrm{~cm}$ and instantaneous beet-seed sowing, STG strip-till to a depth of $25 \mathrm{~cm}$ on white mustard mulch and instantaneous beet-seed sowing. 
Table 6. The number of selected group of microorganisms under the cultivation of sugar beets in 2013 .

\begin{tabular}{|c|c|c|c|c|c|c|}
\hline \multirow{2}{*}{ Term of analysis } & \multicolumn{6}{|c|}{ Experimental combination } \\
\hline & CT & MS35 & MS15 & MG & STS & STG \\
\hline \multicolumn{7}{|c|}{ Total number bacteria $\left(\mathrm{cfu} \cdot \mathrm{g}^{-1} \mathrm{dm}\right.$ soil $\left.\cdot 10^{5}\right)$} \\
\hline Before sowing & $47.41 b-\mathrm{e} \pm 7.4$ & $49.45 b-d \pm 2.1$ & $79.10 \mathrm{a} \pm 4.2$ & $47.95 \mathrm{~b}-\mathrm{e} \pm 2.3$ & $60.95 a-d \pm 3.8$ & $66.50 \mathrm{a}-\mathrm{c} \pm 3.6$ \\
\hline BBCH16/17 & $8.29 \mathrm{~g}-\mathrm{i} \pm 5.2$ & $12.43 \mathrm{f}-\mathrm{i} \pm 1.9$ & $11.68 \mathrm{f}-\mathrm{i} \pm 3.1$ & $23.35 \mathrm{e}-\mathrm{i} \pm 1.7$ & $14.69 \mathrm{f}-\mathrm{i} \pm 3.2$ & $4.89 \mathrm{i} \pm 0.6$ \\
\hline $\mathrm{BBCH} 39 / 40$ & $27.87 \mathrm{e}-\mathrm{i} \pm 2.5$ & $37.74 \mathrm{c}-\mathrm{f} \pm 1.1$ & $38.48 \mathrm{c}-\mathrm{e} \pm 3.3$ & $60.13 \mathrm{a}-\mathrm{d} \pm 2.5$ & $75.41 \mathrm{ab} \pm 2.2$ & $48.10 \mathrm{~b}-\mathrm{e} \pm 2.3$ \\
\hline Technological maturity & $12.34 \mathrm{f}-\mathrm{i} \pm 4.3$ & $12.78 \mathrm{f}-\mathrm{i} \pm 1.3$ & $6.52 \mathrm{~h} \pm 2.1$ & $35.19 \mathrm{~d}-\mathrm{h} \pm 2.9$ & $10.64 \mathrm{f}-\mathrm{i} \pm 1.2$ & $8.40 \mathrm{~g}-\mathrm{i} \pm 1.6$ \\
\hline \multicolumn{7}{|c|}{ Actinobacteria $\left(\mathrm{cfu} \cdot \mathrm{g}^{-1} \mathrm{dm}\right.$ soil $\left.\cdot 10^{5}\right)$} \\
\hline Before sowing & $54.51 \mathrm{~d}-\mathrm{f} \pm 3.5$ & $35.65 \mathrm{e}-\mathrm{i} \pm 5.9$ & $73.45 \mathrm{c}-\mathrm{e} \pm 4.9$ & $24.75 \mathrm{fg} \pm 4.1$ & $26.83 f-g \pm 2.3$ & $32.30 \mathrm{f}-\mathrm{h} \pm 4.3$ \\
\hline ВBCH16/17 & $47.46 \mathrm{~d}-\mathrm{g} \pm 2.1$ & $18.46 \mathrm{fg} \pm 8.6$ & $12.83 .61 \mathrm{~g} \pm 3.6$ & $1.88 \mathrm{i} \pm 0.6$ & $23.73 \mathrm{fg} \pm 3.4$ & $2.64 \mathrm{i} \pm 1.3$ \\
\hline ВBCH39/40 & $102.30 \mathrm{bc} \pm 1.9$ & $79.92 \mathrm{~cd} \pm 4.5$ & $105.45 b c \pm 6.4$ & $135.67 \mathrm{ab} \pm 3.7$ & $156.05 \mathrm{a} \pm 2.4$ & $122.10 \mathrm{~b} \pm 5.5$ \\
\hline Technological maturity & $13.21 \mathrm{~g} \pm 2.2$ & $7.543 \mathrm{~h} \pm 0.9$ & $14.35 \mathrm{~g} \pm 1.08$ & $44.72 \mathrm{~d}-\mathrm{g} \pm 2.2$ & $22.47 \mathrm{fg} \pm 0.6$ & $31.97 \mathrm{f}-\mathrm{g} \pm 1.9$ \\
\hline \multicolumn{7}{|c|}{ Fungi $\left(\mathrm{cfu} \cdot \mathrm{g}^{-1} \mathrm{dm}\right.$ soil $\left.\cdot 10^{4}\right)$} \\
\hline Before sowing & $21.28 \mathrm{a} \pm 2.2$ & $11.1 \pm 2 \mathrm{bc} 4.03$ & $11.68 \mathrm{bc} \pm 4.3$ & $6.96 \mathrm{~d}-\mathrm{f} 2.0$ & $13.80 \mathrm{bc} \pm 2.5$ & $7.22 \mathrm{c}-\mathrm{e} \pm 2.4$ \\
\hline ВBCH16/17 & $1.45 \mathrm{~g} \pm 0.56$ & $2.75 \mathrm{~g} \pm 0.6$ & $4.81 \mathrm{f}-\mathrm{g} \pm 0.7$ & $7.63 c-e \pm 1.2$ & $1.13 \mathrm{~g} \pm 1.1$ & $6.69 \mathrm{~d}-\mathrm{f} \pm 1.7$ \\
\hline ВBCH39/40 & $1.47 \mathrm{~g} \pm 0.50$ & $3.11 \mathrm{~g} \pm 0.10$ & $12.52 b c \pm 1.8$ & $13.26 \mathrm{bd} \pm 2.1$ & $18.40 \mathrm{ab} \pm 0.9$ & $18.56 \mathrm{ab} \pm 1.2$ \\
\hline Technological maturity & $7.33 \mathrm{c}-\mathrm{e} \pm 1.27$ & $5.18 \mathrm{f}-\mathrm{g} \pm 1.6$ & $2.22 \mathrm{~g} \pm 1.1$ & $4.77 \mathrm{f}-\mathrm{g} \pm 0.6$ & $6.13 \mathrm{~d}-\mathrm{f} \pm 0.56$ & $7.03 c-e \pm 1.6$ \\
\hline
\end{tabular}

Mean values \pm standard errors; different letters denote statistical differences at level $\alpha=0.05 ; n=5$

biological life. Agrotechnological procedures influence the distribution of organic substances in soil and thus cause changes in the enzymatic activity and population of soil microorganisms [19].

The results of analyses presented in our research indicate that the populations of selected soil microorganisms differed depending on the cultivation methods and the stage of sugar beet development. In 2012 and 2013 the total number of bacteria was high at the first term of analyses, in the soil where conservation tillage systems were applied (Tables 5-6). In both research years the total number of bacteria were significantly high in the strip-till treatment with sowing into mulch from the white mustard intercrop (STG). In both research years the simplified cultivation systems were observed to have a stimulating effect at the third term, when the rows of sugar beets began to close in. At that term of the analysis, in both research years the highest total number of bacteria was noted for the treatment with strip-till sowing into stubble mulch (STS). At that term of the analysis, this group of microorganisms was also found to exhibit high activity in the soil samples collected from the tillage system at a depth of $15 \mathrm{~cm}$ and sowing into mulch from the white mustard intercrop (MG) and from the strip-till system in mulch from the white mustard intercrop (STG) (Table 5). The research conducted by Małecka et al. [13] revealed that tillage systems had a significant influence on the populations of microorganisms in soil, where the highest number was noted after direct sowing while the lowest number was observed in the plough system. Similar research results were published by Frąc et al. [20] and by Swędrzyńska and Grześ [21].

Our research revealed that conservation tillage systems had a significantly stimulating effect on the population of actinobacteria. Similar to the total number of bacteria, there was a large increase in this group of microorganisms at the third term of analyses, when the rows of plants were closing in. Both in 2012 and 2013 there was a high number of actinobacteria in the soil samples collected from the treatment with strip-till in stubble mulch at a depth of $25 \mathrm{~cm}$ (STS) and in mulch from the white mustard intercrop (STG) (Tables 5-6). The population of actinobacteria was $42 \%$ greater in soil from the sites with the strip-till system with direct sowing of sugar beets into stubble mulch.

The increase in total bacteria numbers and in the population of actinobacteria was a certain regularity observed in both research years when conservation tillage was applied in sugar beet cultivation. According to Niewiadomska [11], actinobacteria are an ecological group of microorganisms that indicate soil fertility. It is noteworthy that some plant residues that enter soil bring some nutrients, and this may have caused the increase in populations of these groups of microorganisms. Bielińska et al. [22] made similar observations in their study, which proved that there was a more intense increase in the number of actinobacteria in soils cultivated with simplified systems, because there were more intense biochemical processes and the soil $\mathrm{pH}$ was optimal for their development. 
Table 7. F-test statistics and significance levels of two-way analysis of variance for the basic parameters of soil activity. Influencing factor on measured parameters were used for tillage systems and terms research fixed factors $(* * * p=0.001$; $* * p=0.01 ; * p=0.05 ;$ ns - not statistically significant).

\begin{tabular}{|c|c|c|c|}
\hline Parameter & Tillage system & Term & Interaction \\
\hline \multicolumn{4}{|c|}{2012} \\
\hline Dehydrogenases & $1.250 \mathrm{~ns}$ & $14.277^{* * *}$ & $1.1025 \mathrm{~ns}$ \\
\hline Acid phosphatase & $1.452 \mathrm{~ns}$ & $33.773^{* * *}$ & $2.061^{*}$ \\
\hline $\begin{array}{c}\text { Alkaline } \\
\text { phosphatase }\end{array}$ & $32.305^{* * *}$ & $439.038^{* * *}$ & $11.1977^{* * *}$ \\
\hline \multicolumn{4}{|c|}{2013} \\
\hline Dehydrogenases & $26.777^{* * *}$ & $324.335^{* * *}$ & $25.043^{* * *}$ \\
\hline Acid phosphatase & $9.212^{* * *}$ & $311.195^{* * *}$ & $6.189^{* * *}$ \\
\hline $\begin{array}{c}\text { Alkaline } \\
\text { phosphatase }\end{array}$ & $13.432^{* * *}$ & $471.495^{* * *}$ & $8.930^{* * *}$ \\
\hline
\end{tabular}

The results presented in Tables 5 and 6 also indicate that when conservation tillage was applied, the population of fungi increased in both years of research. In 2013 the population of moulds was lower than in 2012. This fact may have been caused by higher $\mathrm{pH}$ in the soil $(\mathrm{pH}$ 7.0) (Table 1).

Soil enzymes are good indicators of microbial activity, and simultaneously they indicate the bioprocesses that affect soil fertility and productivity [23-24]. Changes in the activity of soil enzymes reflect environmental disorders, which affect both the soil and plants [6]. Dehydrogenases and phosphomonoesterases (acid and alkaline) are the most commonly investigated soil enzymes [19]. The two-factor analysis of variance proved that the cultivation methods and the growth stages had a highly significant influence $(\alpha=0.001)$ on the degree of biochemical

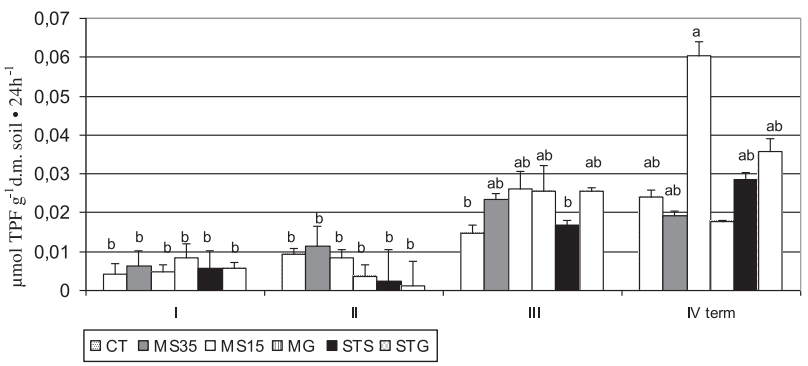

Fig. 1. The activity of dehydrogenases under beete in different tillage system in 2012. Mean values \pm standard errors; different letters denote statistical differences at level $\alpha=0.05 ; n=5$.

Abbreviations for Figs. 1-6: CT - control treatment; MS35 - tillage to a depth of $35 \mathrm{~cm}$ and sowing into stubble mulch; MS15 tillage to a depth of $15 \mathrm{~cm}$ and sowing into stubble mulch; MG tillage to a depth of $15 \mathrm{~cm}$ and sowing into white mustard mulch; STS strip-till on stubble mulch to a depth of $25 \mathrm{~cm}$ and instantaneous beet seed sowing; STG strip-till to a depth of $25 \mathrm{~cm}$ on white mustard mulch and instantaneous beet seed sowing.

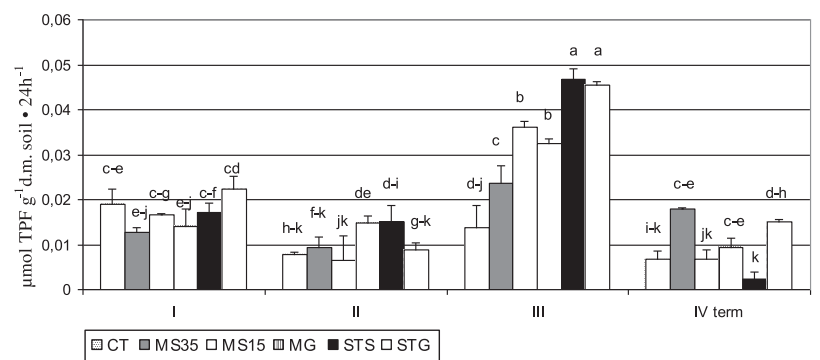

Fig. 2. The activity of dehydrogenases under beets in different tillage systems in 2013. Mean values \pm standard errors; different letters denote statistical differences at level $\alpha=0.05 ; \mathrm{n}=5$.

activity of soil under sugar beets, except for the dehydrogenase and acid phosphomonoesterase activity in 2012 (Table 7).

In comparison with the plough cultivation system (control), in both 2012 and 2013 there were statistically significant $(\alpha=0.001)$ greater values of dehydrogenase activity (DHA) in all of the conservation tillage systems at the third term of analyses, during the growth of sugar beet rosettes (Figs 1-2). The experiments revealed high fluctuations in dehydrogenase activity. In 2012 the enzymes were less active than in 2013, which may have resulted from weather conditions, especially from soil humidity in summer. As early as the 1970s there were studies on the dependence between dehydrogenase activity and current environmental conditions, including

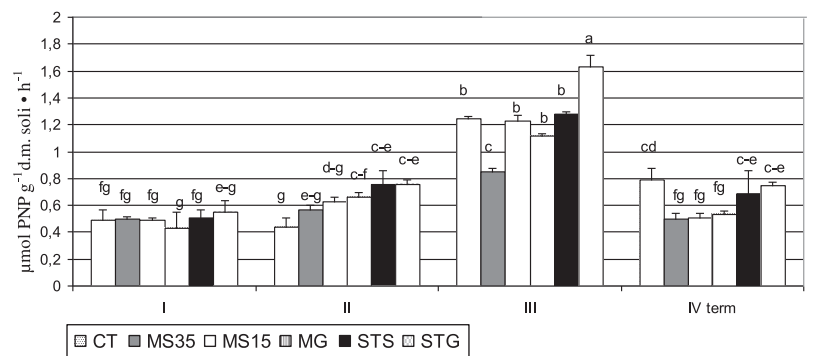

Fig. 3. The activity of alkaline phosphatase under beets in different tillage systems in 2012. Mean values \pm standard errors; different letters denote statistical differences at level $\alpha=0.05$; $\mathrm{n}=5$.

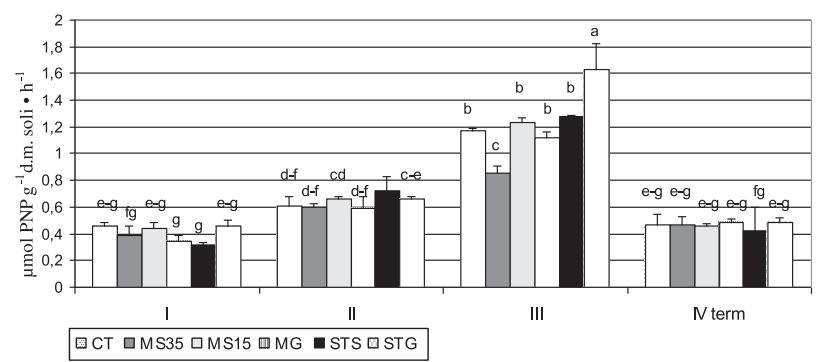

Fig. 4. The activity of alkaline phosphatase under beets in different tillage systems in 2013. Mean values \pm standard errors; different letters denote statistical differences at level $\alpha=0.05$; $\mathrm{n}=5$. 


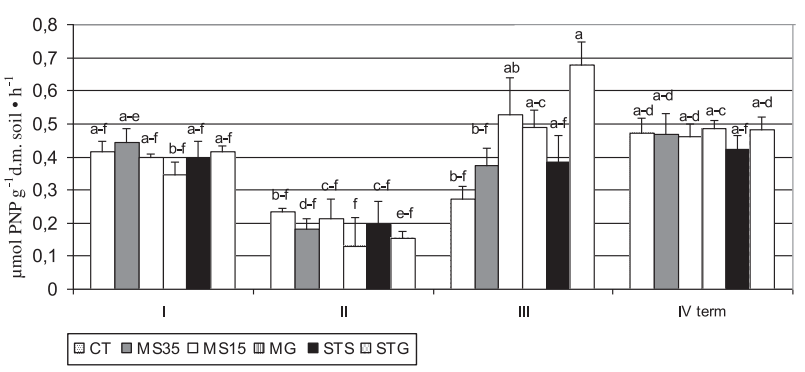

Fig. 5. The activity of acid phosphatase under beets in different tillage systems in 2012. Mean values \pm standard errors; different letters denote statistical differences at level $\alpha=.05 ; \mathrm{n}=5$.

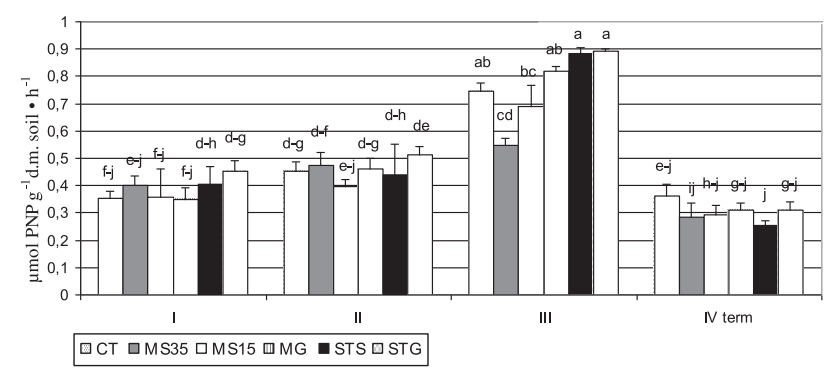

Fig. 6 . The activity of acid phosphatase under beets in different tillage systems in 2013. Mean values \pm standard errors; different letters denote statistical differences at level $\alpha=0.05 ; n=5$.

soil humidity. Whenever there was higher soil humidity, there was always an increase in the DHA [25-26]. Other authors have stated [22] that among the parameters of soil enzymatic activity under analysis alkaline phosphomonoesterase is a good indicator of the activity of soil microorganisms responsible for soil productivity. The results obtained in the field experiments indicate that both in 2012 and 2013 the highest value of this parameter was observed at the third term of analyses for the treatments where strip-till sowing was applied (STS and STG) (Figs 3-4). Similar dependences were noted for the alkaline phosphatase under investigation (Figs 5-6).

There were similar results obtained in the studies by Acosta-Martinez et al. [27] and by Sardans et al. [28], who reported that activities of the phosphatases were more intense in the summer period. According to these authors, the increase in the root weight in the summer generated maximum secretion of enzymes into the rhizosphere, which came both directly from the roots and from the bacteria developing in the rhizosphere.

The dependence between the population of microorganisms and soil enzymatic activity for individual treatments in the periods of analyses are presented as a principal component analysis (PCA) in 2012 and 2013, respectively (Figs 7-8). In the first year of the research the first principal component explains $40.02 \%$ of variability, and the other explains $27.74 \%$, which amounts to $67.76 \%$ of total variability. On the other hand, in the second year the values were $70.18 \%$ and $19.11 \%$, respectively, which amounts to $89.29 \%$ of variability.

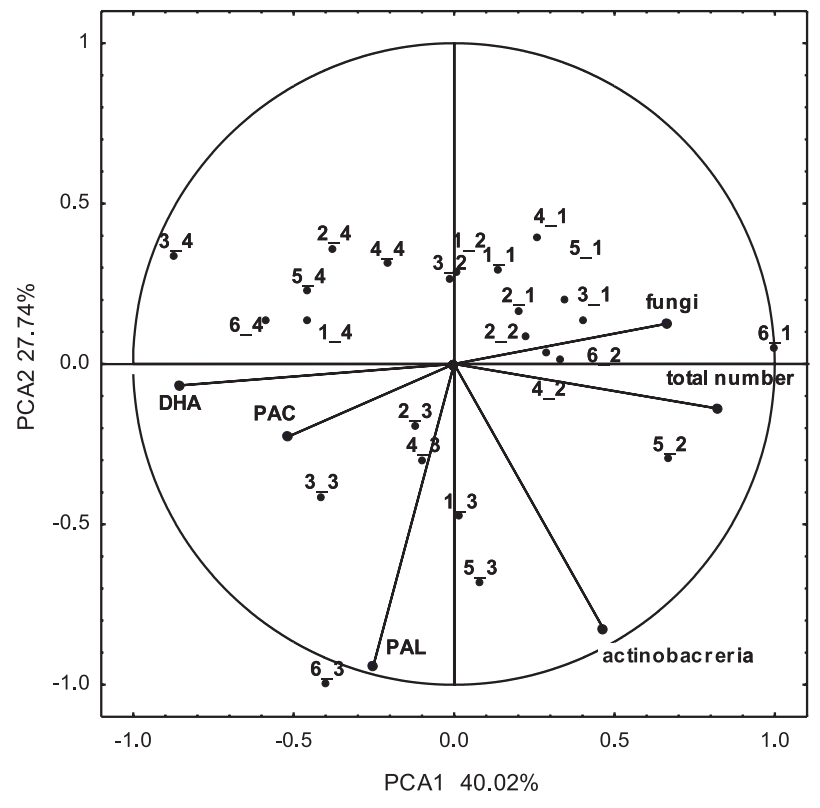

Fig. 7. The dependence between the population of microorganisms and soil enzymatic activity for all treatments at the terms of analyses in 2012.

Abbreviations: 1_1 - CT, before sowing; 2 1 - MS35, before sowing; 3_1 MS15, before sowing; 4_1- MG, before sowing ; 5_1-STS, before sowing; 6_1 STG, before sowing; 1_2 - CT, emergence; 22 MS35, emergence; 32 MS15, emergence; 42 MG, emergence; 5_2 STS, emergence; 6_2 STG, emergence; $1 \_3-\mathrm{CT}$, the stage of plants closing rows; 23 - MS35, the stage of plants closing rows; 3 _ - MS15, the stage of plants closing rows; $4 \_3-\mathrm{MG}$, the stage of plants closing rows; $5 \_3-\mathrm{STS}$, the stage of plants closing rows; $6 \_3-$ STG, the stage of plants closing rows; 1_4 - CT, technological maturity, 2_4 - MS35, technological maturity; 3_4- MS15, technological maturity; 4_4 MG, technological maturity; 5 4-STS, technological maturity; $6 \_4$ - STG, technological maturity. PAC - acid phosphatase; PAL - alkaline phosphatase; DHA - dehydrogenases.

The dependences resulting from the research point to the stimulating effect of conservation tillage on increased biological activity in soil, which indicate its high productivity. In both 2012 and 2013 we observed a close relationship between the population of microorganisms from the ecological group (actinobacteria) and alkaline phosphatase activity. Apart from that, in 2013 we noted a strong relationship between dehydrogenase activity and actinobacteria and between phosphomonoesterases ( $\mathrm{Pal}$ and $\mathrm{Pac}$ ) and the number of fungi and the total bacterial count. The absence of some dependences in 2012 may have been caused by unfavourable weather conditions (Table 3). In 2012 there was lower rainfall, which resulted in lower soil humidity. It had a significant influence on the enzymatic activity and population of actinobacteria in the soil. The decrease in the content of water inhibits the development of certain groups of microorganisms, and thus it causes a decrease in their population and a decrease in so-called inductive enzymes, whose microorganisms secrete into soil. Furczak and Turska [29] confirm the diversified dynamics of microbial changes during vegetation. 


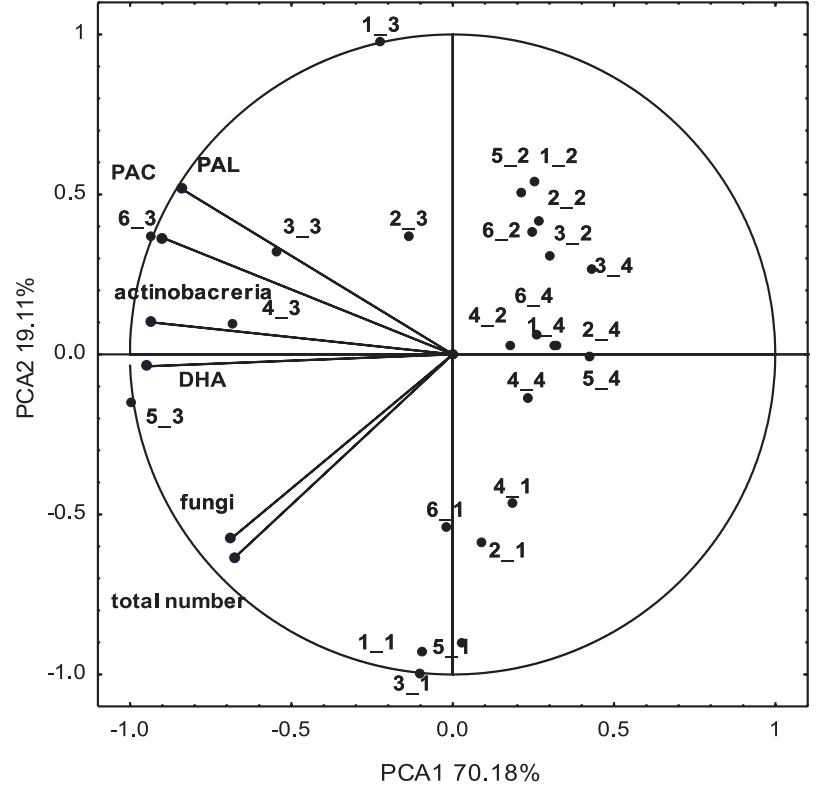

Fig. 8. The dependence between the population of microorganisms and soil enzymatic activity for all combinations at the terms of analyses in 2013.

Abbreviations: $11-\mathrm{CT}$, before sowing; 21 - MS35, before sowing; 3_1 MS15, before sowing; 4_1-MG, before sowing ; 51 -STS, before sowing; 61 STG, before sowing; 12 - CT, emergence; 2_2 MS35, emergence; 3_2 MS15, emergence; 4_2 MG, emergence; 5_2 STS, emergence; 6_2 STG, emergence; 13 -CT, the stage of plants closing rows; $23-\mathrm{MS} 35$, the stage of plants closing rows; 3 - 3 -MS15, the stage of plants closing rows; 4_3 - MG, the stage of plants closing rows; $5 \_3-\mathrm{STS}$, the stage of plants closing rows; $6 \_3-$ STG, the stage of plants closing rows; 1_4 - CT, technological maturity, 2_4 V MS35, technological maturity; 3 4- MS15, technological maturity; 44 - MG, technological maturity; 5 -4 - STS, technological maturity; 64 - STG, technological maturity. PAC - acid phosphatase; $\mathrm{PAL}$ - alkaline phosphatase; DHA - dehydrogenases.

\section{Conclusion}

From the microbiological point of view the research findings should be regarded as promising. The two years of field experiments with simplified or limited cultivation by eliminating soil tillage procedures through aggregation of cultivation tools, eliminating or reducing the depth of deep tillage, strip cultivation, and direct sowing of sugar beets into mulch resulted in increased enzymatic and microbial activity. It is necessary to stress the fact that in both 2012 and 2013 the highest bioactivity was noted in the period of the greatest demand of sugar beets for nutrients, i.e., at the BBCH39/40 phase, when the rows of plants were closing in. At that time the content of actinobacteria in the soil collected from the sites where the strip-till system with direct sowing of sugar beets into stubble mulch (STS) had been applied was $42 \%$ greater than in the soil from the ploughing cultivation system. The increase in the population of this group of microorganisms indicates soil fertility and productivity.

There were frequent diversifications in the enzymatic activity in individual treatments of the cultivation system.
Whenever conservation tillage was applied, the soil enzymatic activity always increased. This dependence was particularly noticeable in Pal and Pac phosphatases at the third term of analysis, when the system of strip-till to a depth of $25 \mathrm{~cm}$ on white mustard mulch and instantaneous beet seed sowing (STG) was applied. In comparison with the traditional cultivation system, there was a $46 \%$ increase for the alkaline phosphatase and a 33\% increase for the acid phosphatase, respectively.

\section{References}

1. DZIENIA. S., ZIMNY L., WEBER R. Recent trends in tillage and sowing technique. Bibliotheca Fragm. Agron. 9, 17, 2005.

2. RAJEWSKI J., ZIMNY L., KUC P. Effect of different variants of conservation tillage on the technological value of sugar beet roots. Problem of Agric. Engine. 1, 109, 2008 [In Polish].

3. KUC P., TENDZIAGOLSKA E. Sugar beet yielding in varying variants of tillage. Fragm. Agron. 28 (3), 63, 2011 [In Polish].

4. WEBER R. The impact of growing conservative on environmental protection. Prog. Agric. Sci. 1, 57, 2002 [In Polish].

5. KLADIVKO E.J. Tillage system and soil ecology. Soil Till. Res. 61, 61, 2001.

6. BIELIŃSKA E.J., MOCEK-PŁÓCINIAK A. Impact of the tillage system on the soil enzymatic activity. Arch. Environ. Prot. 38 (1), 75, 2012.

7. GU Y., WAG P., KONG C. Urease, invertase, dehydrogenases and polyphenoloxidase activites in paddy sols influenced by allelophatic rice variety. Euro. J Soil Biol. 45, 436, 2009.

8. BRZEZIŃSKA M. The biological activity and its associated processes in organic soils irrigated with purified municipal sewage. Acta Agrophys. 131 (2), 1, 2006.

9. MOESKOPS B., BUCHAN D., SLEUTEL S., HERAWATY L., HUSEN E., SARASWATI R., SETYORINI, D., DE NEVE S. Soil microbial communities and activities under intensive organic and conventional vegetable farming in west Java, Indonesia. Appl. Soil Ecol. 45, 112, 2010.

10. ZHAO B., CHEN J., ZHANG J., QIN S. Soil microbial biomass ad activity response to repeated drying - rewetting cycles along a soil fertility gradient modified by long term fertilization management practices. Geoderma 160, 218, 2010.

11. NIEWIADOMSKA A., SAWIŃSKA Z., WOLNA-MARUWKA A. Impact of selected seed dressing on soil microbiological activity in spring barley cultivation. Fresen. Environ. Bull. 20 (5a), 1252, 2011.

12. NIEWIADOMSKA A., SULEWSKA H., WOLNA MARUWKA A., KLAMA J. Effect of organic fertilization on development of proteolytic bacteria and activity of proteases in the soil for cultivation of maize (Zea Mays L.) Arch. Environ. Prot. 36 (2), 47, 2010.

13. MAŁECKA I., SWĘDRZYŃSKA D., BLECHARCZYK A. DYTMAN-HAGEDORN M. Effect of tillage system on the physical, chemical and biological parameters in cultivation of the peas. Fragm. Agron. 29 (4), 106, 2012.

14. MARTIN J.P. Use of acid, rose Bengal and streptomycin in the plate method for estimating soil fungi. Soil Sci. 15, 215, 1950.

15. GRABIŃSKA-ŁONIEWSKA A. Laboratory classes in general microbiology. Oficyna Wydaw. Politech. Warszawa. 1999 [In Polish]. 
16. THALMANN A. Zur methodik der bestimmung der dehydrogenase aktivität in boden mittels triphenyltetrazoliumchlorid (TTC). For methodology the determination of dehydrogenase activity in soil means triphenyltetrazolium (TTC). Landwirtschaft Forsh. 21, 3, 1968 [In German].

17. TABATABAI M.A., BREMNER J. Use of P-nitrophenyl phosphate for assays of soil phosphatase activity. Soil Biol. Biochem. 1, 301, 1969.

18. AHEMAD M., ZAIDI A., KHAN S., OVES M., Factors affecting the variation of microbial communities in different agro ecosystems. In: Microbial Strategies for crop improvement. Springer, Berlin Heidelberg: 301, 2009.

19. SALAZAR S., SANCHEZ L., ALVAREZ J., VALNERDE A., GALINDO P., IGUAL J., PEIX A., SANTA-REGINA I. Correlation among soil enzyme activities under different forest system management practices. Ecol. Eng. 37, 1123, 2011.

20. FRĄC M., LIPIEC J., RUTKOWSKA A., OSZUST K., PÓŁTORAK M. Microbiological properties of soil under cultivation of winter wheat in organic and conventional systems. Acta Agrophys. 18 (2), 245, 2011.

21. SWĘDRZYŃSKA D., GRZEŚ S. Microbiological parameters of soil under sugar beat as a response to the long - term application of different tillage systems. Pol. J. Environ. Stud. 24 (1), 285, 2015.

22. BIELIŃSKA J., FUTA, B., MOCEK-PŁÓCINIAK A. Soil enzymes as bio-indicators of soil health and quality. Libropolis Lublin. 2014 [In Polish]
23. NORTCLIFF S. Standardisation of soil quality attributes. Agr. Ecosyst. Environ. 88, 161, 2002.

24. TIAN Y., ZHANG X., LIU J., CHEN Q., GAO L. Microbial properties of rhizosphere soils as affected by rotation grafing and soil sterilization in intensive vegetable production systems. Sci. Hort. 123, 139, 2009.

25. NAYAKA D.R., BABU J., ADHYA T.K. Long - term application of compost influence microbial biomass and enzyme activities in a tropical Aeric Endoaquept planted to rice under flood condition. Soil Biol. Biochem. 39, 1897, 2007.

26. PASCUAL I., ANTOLIN M.C., GARCIA C., POLO A., SANCHEZ-DIAZ M. Soil microbial activity as biomarker of degradation and remediation processes. Soil Biol. Biochem. 32, 1877, 2007.

27. ACOSTA-MARTINEZ V., ACOSTA-MERCADO D., SOTOMAYOR-RAMIREZ D., CRUZ-RODRIGUEZ L. Microbial communities and enzymatic activities under different management in semiarid soils. Appl. Soil Ecol. 38, 249, 2008.

28. SARDANS J., PEŇUELAS J., ESTRIARTE M. Warming and drought alter soil phosphatase genes in soil supplied with organic matter. Plant Soil. 289, 227, 2006.

29. FURCZAK J., TURSKA B. Influence of different soybean cultivation systems on development of microorganisms and phenols content in loess soil. Acta Agrophys. 8 (1), 59, 2006. 